\title{
Marx is Back, But Which One? On Knowledge Labour and Media Practice
}

\author{
Vincent Mosco
}

Queen's University, Kingston, Canada, moscov@mac.com, http://www.queensu.ca/sociology/people/emeritusfaculty/mosco.html

\begin{abstract}
The global economic crisis has led to a resurgence of interest in the work of Karl Marx. This paper acknowledges this interest, but asks on which of the many shades of Marx, communication scholars should be focusing their research attention. The most general answer is all of Marx, from the early work on consciousness, ideology and culture, which has informed critical cultural studies through to the later work on the structure and dynamics of capitalism that provides bedrock for the political economy of communication. But there is particular need for communication scholars to pay more attention to work that does not fit so neatly in either of these foci, namely, Marx of the Grundrisse and Marx, the professional journalist. Communication scholars need to do so because we have paid insufficient attention to labour in the communication, cultural and knowledge industries. The Marx of these two streams of work provides important guidance for what I have called the labouring of communication as well as for addressing general problems in communication theory.
\end{abstract}

Keywords: Grundrisse, journalism, labor, Marx, political economy,

Acknowledgement: This paper was supported by a grant from the Canadian Social Sciences and Humanities Research Council. I am grateful for the research assistance of four graduate students at Queen's University: Meagan Crane, Dean Curran, Harrison Smith, and Erica Spink.

\section{Marx is Back}

The global economic crisis that filled the headlines beginning at the end of 2008 led to a resurgence of popular interest in the work of Karl Marx. Those of us who made use of this body of thought for many years questioned whether he had ever left, but that was beside the point, as the media were filled with anecdotal accounts of strange sightings and even stranger sound bites. The Times of London led the charge on October 21, 2008 when, as capitalism appeared to be crumbling, the normally stodgy newspaper declared in a headline: "Marx is Back". The Times of India wrote about "Marx in the time of pink slips" (Saxena 2008). Das Kapital rose up the best seller list in Germany and, across the border, Nicholas Sarkozy, never one to miss a photo opportunity, was snapped leafing through a copy. Even Pope Benedict was quoted as praising Marx's "great analytical skill" (Kapital Gains 2008). Not to be outdone, the Archbishop of Canterbury praised Marx for demonstrating that "capitalism became a kind of mythology", charging that its boosters were engaging in nothing short of "idolatry" (Gledhill 2008). This strange dalliance with the theorist of revolution continued well into 2011 as evidenced by a story in Bloomberg Businessweek which declared in a story "Marx to Market" that "The Bearded One has rarely looked better" (September 14, 2011). Indeed a headline in Canada's national newspaper declared that it was "Springtime for Marx" (Renzetti 2011).

Marxist scholars, accustomed to toiling in relative obscurity, were courted by mainstream media to explain these developments. Foreign Policy magazine featured Leo Panitch's article "Thoroughly Modern Marx" on its cover (Panitch 2009). Invited to lunch with George Soros, Eric Hobsbawn worried about whether he would have to tiptoe around radical talk, only to have one of the world's leading financiers admit that Marx "discovered something about capitalism 150 years ago that we must take notice of" (Renzetti 2011).

One can certainly make too much of all this Marx talk. As government bailouts calmed the markets, the homage to Marx has diminished. But it still resonates enough for me to turn my attention to the relevance of Marx's thought for communication theory. Specifically, this paper focuses on two neglected dimensions of Marx's work that are of particular relevance to media and communication scholars.

\section{But which one?}

One of my first thoughts on facing the prospect of writing about Marx is to wonder about which of the many persona of Marx one should emphasize. It is clear that the media care about Marx the political economist and revolutionary who provided at least some food for thought about what was 
for them the shocking meltdown of financial markets and the deepening fears for the future of capitalism. This is certainly understandable and I am no stranger to the task of documenting the importance of this Marx, the Marx of Capital and political economy, for understanding global communication. Yet there is another Marx not unrelated to the first whose writing about culture and ideology featured in The German Ideology, The Economic and Philosophical Manuscripts, and other works of the younger Marx have inspired analysis and critique in cultural studies. It is not an exaggeration to conclude that the Marx of political economy and of cultural studies form pillars of critical communication study.

Nevertheless, an exclusive emphasis on this bifurcated "young Marx/culture - old Marx/political economy" risks missing two other key elements of Marx that are vital to contemporary communication studies. Indeed, although I admit that there are many ways to divide Marx, one particularly useful one is to see him in four parts- and no, I do not mean Groucho, Harpo, Chico and Zeppo. In addition to the Marx of political economy and the Marx of cultural studies, there is the Marx of his famous, and also infamous, notebooks The Grundrisse and the work of Marx the professional journalist. Indeed although Marx practiced journalism throughout his life, both The Grundrisse and the best of Marx's journalism bridged the critical period between the earlier and later years of his career.

\section{The Grundrisse}

What has come to be called the Grundrisse is actually a collection of seven notebooks written over the period 1857-58, midway between the Manifesto and the first volume of Capital. They were produced in the midst of one of capitalism's first great economic crises, certainly its first crisis of overproduction. The notebooks have been depicted conventionally, by Martin Nicolaus (1973), as the precursor to Capital. They also have been described less conventionally by Nick DyerWitheford as "the delirious notebooks" which "Marx used to prophesy a moment when capital's development would depend not on the direct expenditure of labour power in production but rather on the mobilization of social and scientific knowledge"1. I encountered the Grundrisse as a graduate student when the first English translation appeared and joined the applause of young Marxists who were now offered fresh material to digest, debate and use. It did not dim my enthusiasm when former Marxists like my thesis supervisor Daniel Bell rejected the new work as of little use for understanding Marxist thought.

There are good reasons to see the Grundrisse as anticipating key arguments in Capital and in other later works. But it also explores themes that Marx never had the time to develop in a sustained fashion and some of these have been taken up in contemporary Marxist scholarship. As he would do in Capital, Marx acknowledges the contribution of technology and especially that of new communication media like the telegraph for the expansion of global capitalism. For Marx, "Capital by its nature drives beyond every spatial barrier. Thus the creation of the physical conditions of exchange - of the means of communication and transport the annihilation of space by time - becomes an extraordinary necessity for it. Only in so far as the direct product can be realized in distant markets in mass quantities in proportion to reductions in the transport costs, and only in so far as at the same time the means of communication and transport themselves can yield spheres of realization for labour, driven by capital; only in so far as commercial traffic takes place in massive volume - in which more than necessary labour is replaced - only to that extent is the production of cheap means of communication and transport a condition for production based on capital, and promoted by it for that reason" (Marx 1973, 524).

This passage captures the dual nature of communication in capitalism. It contributes to the commodification of all productive forces and it becomes a commodity in its own right. In the process, communication technology becomes a key tool, along with the development of the means of transportation, in the spatial expansion of capitalism, what we now call globalization. At another point in this work, Marx makes clear that commodification and spatialization are intimately connected to the process of structuration, the development of social relations, including new forms of communication: "Not only do the objective conditions change in the act of reproduction, e.g., the village becomes a town, ..., but the producers change too, in that they bring out new qualities in themselves, develop themselves in production, transform themselves, develop new powers and ideas, new modes of intercourse, new needs and new language" (Marx 1973, 494).

These ideas are central to developing a Marxist theory of communication. They both build upon the early work and prepare the way for Capital. But the Grundrisse is much more than a way sta-

http://www.fims.uwo.ca/peopleDirectory/faculty/fulltimefaculty/full time faculty profile.htm?Peopleld=3667; see also Piccone 1975 
tion on the long march to Capital, a point missed by one of the first scholars to bring the Grundrisse to an English-speaking world. The critical difference between this work and Capital is not the difference between the creative display of a work in progress and a fully formed creation, as Nicolaus maintains. Rather, the Grundrisse is, however dishevelled or even delirious, a substantive creation in its own right and a touchstone for vital developments in critical communication research. It contains ideas that Capital never got around to addressing but which matter considerably to scholarship and politics today.

In the Grundrisse, Marx focuses explicit attention on the significance of information for capital. This is expressed in numerous different ways roughly signifying, at different times, social knowledge, the state of scientific and artistic knowledge, and the general intellect. In essence, one of the most important consequences of a developing capitalist economy is that it provides free time to think, create, and advance the general state of scientific, technical and artistic information. Capitalism aims to incorporate this expansion of individual and social capacity into the production process, but faces the resistance of increasingly knowledgeable and empowered workers. In the very process of its development capitalism produces the conditions for its expansion and for resistance from workers who increasingly have the opportunity to advance their own creative ability. In the emphasis on technology, on the material machinery of production that is understandably derived from a reading of Capital, one can miss a central point made in the notebooks: the most important embodiment of fixed capital is not the assembly line but "man himself".

In the Grundrisse, as nowhere else, the source of value is information, the creative worker, what some would today call human capital: "Nature builds no machines, no locomotives, railways, electric telegraphs, self-acting mules etc. These are products of human industry; natural material transformed into organs of the human will over nature, or of human participation in nature. They are organs of the human brain, created by the human hand; the power of knowledge, objectified. The development of fixed capital indicates to what degree general social knowledge has become a direct force of production, and to what degree, hence, the conditions of the process of social life itself have come under the control of the general intellect and been transformed in accordance with it" (Marx 1973, 706). The determination of value, a concept central to Marx's political economy, comes to be based firmly on the creative individual: "it is neither the direct human labour he himself performs, nor the time during which he works, but rather the appropriation of his own general productive power, his understanding of nature and his mastery over it by virtue of his presence as a social body - it is, in a word, the development of the social individual which appears as the great foundation-stone of production and of wealth" (Marx 1973, 705).

As capitalism comes to be based increasingly on control over creative ability, and therefore over information, it must mobilize all social institutions involved in producing information. Hence the need for the commodification of the entire creative apparatus, something that can only be achieved "when large industry has already reached a higher stage, and all the sciences have been pressed into the service of capital." As result, "Invention then becomes a business, and the application of science to direct production itself becomes a prospect which determines and solicits it" (Marx 1973, 704).

Because information becomes increasingly central to capitalist development, it is important to consider what Marx means by information. This is difficult because Marx uses a multiplicity of expressions to encompass it. Nevertheless, it is clear that he means more than merely technical knowledge because he uses words that connote both artistic and experiential knowledge. For example, in discussing the contradiction between capital's need to reduce labour time and the need to use it as a measure of social wealth, he refers to the importance for capital of the "artistic, scientific etc. development of individuals in the time set free" (Marx 1973, 706). Again, in a rousing conclusion to a section on economic history, Marx asks what is left of the bourgeois concept of wealth once its limited form is stripped away: "... the universality of individual needs, capacities, pleasures, productive forces, etc. created through universal exchange. ... The absolute working-out of his creative potentialities, with no presupposition other than the previous historic development, which makes the totality of development, i.e., the development of all human powers as such, the end in itself, not as measured on a predetermined yardstick?" (Marx 1973, 488).

This and the accompanying passages demonstrate that while scientific and technical knowledge are important components of an expanding sphere of information, the point of raising its significance does not end there. That is because information is more significantly a marker for the development of full human capacities, including the scientific but also the artistic, the experiential and, certainly, the creative.

Undoubtedly those familiar with Marx's Economic and Philosophical Manuscripts, will note distinct similarities. But a key difference in the Grundrisse is that the discussion of the full develop- 
ment of human powers is now presented within a well-grounded materialist theory of capitalism. The bourgeois world makes it essential that people develop their capacities, but it is so constrained by its own needs for self and social class preservation that it has to restrict this process or be overrun by its consequences. Subsequent work of Marx would provide a more thorough understanding of capitalism, but it does so without returning to the full consideration of the consequences of its own creation. It is the Grundrisse that holds out the potential of actually building on the forces of that creation: information, knowledge, artistic, and experiential capability.

The focus on social information or the general intellect has significant implications for the study of labour and especially for labour in the communication industries. First, in the Grundrisse Marx acknowledges that however new the industrial world might be, it too was rapidly changing. Just as capitalism needs to commodify all of the creative industries, including science, to accomplish its goals, it must extend the commodification process to every individual's general productive capacity: "No longer does the worker insert a modified natural thing as middle link between the object and himself; rather, he inserts the process of nature, transformed into an industrial process, as a means between himself and inorganic nature, mastering it. He steps to the side of the production process instead of being its chief actor. In this transformation, it is neither the direct human labour he himself performs, nor the time during which he works, but rather the appropriation of his own general productive power, his understanding of nature and his mastery over it by virtue of his presence as a social body - it is, in a word, the development of the social individual which appears as the great foundation-stone of production and of wealth" (Marx 1973, 705).

Nevertheless, as Marx describes it, the process of ever more deeply commodifying labour, including both intelligence and affect, demonstrates the need to expand these very human capacities. Capital no longer needed just the labourer as appendage to a machine; it needed then and needs now the full "social body" of the individual. This passage and other likes it acknowledge, at a remarkably early stage in capitalist development, the requirement for knowledge and affective labour. Capital needs to create the worker in its fullest subjectivity and then make it part of a process that channels that subjectivity into productivity. On the one hand such a process holds great potential for expanding capitalism into what we now call the knowledge, culture, and information industries. On the other hand, controlling such labour is far more challenging than it is to control and channel manual labour whose knowledge and affect were less consequential to meet the needs of capital. In essence, the Grundrisse suggests that understanding the labour of knowledge, cultural, and creative workers is central to understanding the future of capitalism. What is capital's capacity to control these workers? What are their capacities for resistance? What is capital's ability to control their labour process and what is their ability to give it new direction? It is the very utopian quality of many of the notebooks' passages, ("the absolute working-out of his creative potentialities"), that makes it so powerful because it acknowledges just how important are the stakes in this struggle. It is not just a matter of understanding or even of dismantling capitalism, which fills the pages of Capital, it is also a matter of appreciating what is to be won, i.e., full control over one's humanity, including the creative potential of both intellect and affect.

This brief overview could only paint a picture in the broadest strokes, suggesting why it is absolutely vital for communication scholars to make use of the Grundrisse in research on communication labour and in the wider political economy of communication. There is much more to be addressed in the notebooks themselves as well as in interpretations offered by Piccone (1975), Hardt and Negri (2004), (Negri 1991), Terranova (2004), Dyer-Witheford (1999), Gorz (2010), and others. It is now important to turn to another facet of Marx that is intimately related to the theoretical questions raised in the Grundrisse: the life of Marx as a journalist or professional knowledge worker.

\section{Marx the Journalist}

Scholars who teach about Marx in communication programs focus exclusively on his theoretical writing and tend not to have much to say about Marx as a journalist. There are exceptions, particularly in the work of the critical journalism scholar Hanno Hardt (2001). On the other hand, professors who teach journalism practice exclude Marx completely. When academic journalism instructors do treat Marx, it is typically by equating his views with the totalitarian Marxism of Soviet and Chinese communism. This is unfortunate because there is a great deal to learn about journalism from an analysis of Marx's career as a professional communicator. For a genuine appreciation of Marx the theorist is significantly diminished without consideration of his journalism. Indeed the eminent political philosopher Isaiah Berlin maintains that it was in the course of putting together a story in 1843 that Marx came to recognize "his almost total ignorance of history and principles of economic development" and leapt into the formal study of political economy (Berlin 1970, 12). Moreover, there is a close connection between Marx's Grundrisse and his journalism. Although he prac- 
ticed journalism throughout his life, arguably Marx's best journalism came in the "middle" period of his life, as he was producing the notebooks. In essence, Marx's most interesting theoretical reflections on what we have come to call knowledge and immaterial labour were penned at about the same time that Marx engaged in his most mature work of knowledge labour as a journalist.

It is a remarkable fact, one passed over all too casually, that one of the most profound social theorists of the nineteenth century, someone whose work continues to resonate powerfully today, also practiced the craft of journalism throughout his life. It all the more stunning that his journalism takes up a full seven volumes of the fifty that comprise his collective works. Marx's journalism was most intensive in two periods, in the early years when at age 24 he wrote for and soon thereafter took on the job of editor in chief of the Rheinische Zeitung and then again as writer and editor for the Neue Rheinische Zeitung in Prussia. He decided to pursue journalism because, like so many new PhDs today, he could not find an academic job, particularly under the stifling controls over the university that the Prussian government fiercely enforced. His journalism work in this period focused on investigations into the authoritarian political establishment of Prussia and included numerous articles on censorship and freedom of the press, which landed him in constant difficulties with the authorities, ultimately leading to his banishment from Prussia. Marx produced his most mature works of journalism in the period 1852-62 when he became a foreign correspondent for the New York Tribune, a newspaper founded by Horace Greeley, a leader in the American anti-slavery movement. Greeley's goal was to counter the dominant sensationalist press with in-depth coverage of news and public affairs. Marx wrote from London, where he spent the last half of his life.

Marx's journalism consistently follows principles that provide valuable lessons for any journalist, but especially for those learning about what it means to practice journalism. Moreover, they are principles that also begin to emerge in the Grundrisse and which might apply in varying degrees to all knowledge workers. Throughout his career in journalism Marx was consistently opposed to all forms of censorship and regularly made the case for free expression. Consider this assessment of a proposed new censorship law in Prussia: "Censorship brings us all into subjection, just as in a despotism everybody is equal, if not in worth, then in unworthy; it's a kind of press freedom that wants to introduce oligarchy into the mind. At best, censorship declares a writer to be inconvenient, unsuitable within the boundaries of its domain. Freedom of the press proceeds on the presumption of anticipating world history, sensing in advance the voice of the people which alone has hitherto judged which writer was 'competent' which 'incompetent' " (Marx 1974, 43).

When Americans like Thomas Jefferson wrote lines like this, they were venerated as champions of freedom. Marx typically does not enjoy the same response, not when he wrote them and not now. Harassed by the censor and ultimately the police and government officials, he was made to resign from the newspaper, which itself was disbanded by the authorities.

Nevertheless, Marx followed this principle throughout the rest of his life, but in the 1850s focused more of his critical attention on the growing tendency of self-censorship in the media. The Tribune was widely read throughout the United States and its editors, though progressive and generally supportive, would engage in their own forms of harassment. For example, they would sometimes refuse to publish an article because of its political tone, would soften the content and lift his byline. Even worse, his editors would often insert remarks that distanced the paper from Marx's ideas like this one that appeared after his byline in one piece: "Mr. Marx has very decided opinions of his own, with some of which we are far from agreeing" (Ledbetter 2007, xx). Not one to back down, he consistently fought with his own editors to resist their editorial censorship which often made for colourful comments like this one to Engels in 1857: "It's truly nauseating that one should be condemned to count it a blessing when taken aboard by a blotting-paper vendor such as this" (ibid.).

In spite of these attacks, Marx continued to practice journalism because of his commitment to the principle that journalism was not just a vocation or a calling, but a political calling. He recognized that a newspaper like the Tribune did more than help to pay his bills; it provided him with a platform to reach a wide audience which, at the time he wrote for it, counted 200,000 in its circulation, including Abraham Lincoln who read it avidly (Nichols 2011, 61-100). Marx had his own outlets in what we would today call "alternative" media, but these reached far fewer people. In essence, radical though he was, Marx recognized the importance of working for a mainstream publication to widely circulate his central ideas. There is no doubt that his struggles to use journalism to help bring about political change, including walking a tightrope with a mainstream newspaper, took its toll on his spirit and on his writing. Again, complaining to Engels: "To crush up bones, grind them and make them into soup like paupers in the workhouse- that is what the political work to which one is condemned in such large measure in a concern like this (the Tribune) boils down to" (Ledbetter 2007, xx). Although the counter-revolution of 1848 left him less hopeful that revolution 
was imminent, Marx's journalism continues to reveal the urgency of his political mission. As one recent commentator notes in an insightful assessment: "And yet, reading through Marx's Tribune dispatches, you can't help but see an urgency, an excitement - almost an impatience - in his portrayals of some insurrections and crises in Europe and India. At times he wrote as if this particular rise in corn prices, or this little dust-up with authorities in Greece, was going to be THE spark that would ignite revolution. And it's not as if one can fault Marx for feeling that way; after all, during this period crowned heads of Europe were toppling and certainly at least liberal revolutions seemed likely in a number of settings. But there are times when his discipline of thought appears to leave him, and he is also prone to the tautology that revolution can only occur when the masses are ready, but we can't know for certain if the masses are ready until they create a revolution" (Sherman 2011).

In addition to holding fast to the principles of free expression and journalism as a political calling, Marx used his journalism to give attention to the critical issues facing the world. His was certainly not the journalism of on scene reporting and of interviews with official and unofficial sources. On the latter, the well-known journalist Murray Kempton wrote of Marx: "Of all the illusions one brought to journalism, the one most useful to lose is the illusion of access to sources. ... Persons privy to events either do not know what is important about them or, when they do, generally lie.... Marx had neither the temptation nor the opportunity of access" (Ledbetter 2007, xix). Rather, his approach was to take an event in the news such as the second Opium War in China or the American Civil War and, using the most up-to-date material, address its political economic significance. In this respect he did not disappoint. His writing for the Tribune covered imperialism, including major work on China and India, free trade, war and revolution in Europe, British politics and society, the changing world of economics and finance, and the slave question in America.

Marx's writing on China and India in the context of British domination and the mythology of free trade was among the best of the time and is well worth reading today in light of the West's increasingly uncomfortable relationship with these two Asian powers. As one commentator has put it: "With the possible exception of human slavery, no topic raised Marx's ire as profoundly as the opium trade with China" (Ledbetter 2007, 1). This passage conveys some of its depth and passion:

The Indian finances of the British Government have, in fact, been made to depend not only on the opium trade with China, but on the contraband character of that trade. Were the Chinese Government to legalize the opium trade simultaneously with tolerating the cultivation of the poppy in China, the Anglo-Indian exchequer would experience a serious catastrophe. While openly preaching free trade in poison, it secretly defends the monopoly of its manufacture. Whenever we look closely into the nature of British free trade, monopoly is pretty generally found to lie at the bottom of its 'freedom' (Marx 2007b, 31).

And where is the allegedly free Western media in all of this? His response is worth citing at length:

How silent is the press of England upon the outrageous violations of the treaty daily practiced by foreigners living in China under British protection! We hear nothing of the illicit opium trade, which yearly feeds the British treasury at the expense of human life and morality. We hear nothing of the constant bribery of sub-officials, by means of which the Chinese Government is defrauded of its rightful revenue on incoming and outgoing merchandise. We hear nothing of the wrongs inflicted 'even unto death' upon misguided and bonded emigrants sold to worse than Slavery on the coast of Peru and into Cuban bondage. ... Thus, the English people at home, who look no farther than the grocer's where they buy their tea, are prepared to swallow all the misrepresentations which the Ministry and the Press choose to thrust down the public throat (Marx, 2007a, 23-4).

Marx's journalism provides a central example of his praxis, the unity of theory and practice, that animated his life. It is also full of examples of what journalism can be when it rises above the conventions that sometimes contribute to good writing but often make it difficult to practice the principles that guided his work. These include complete commitment, whatever the cost, to freedom of expression and opposition to censorship, complete belief in journalism as a political calling, and an unrelenting focus on the major issues facing the world. It does not surprise me to read one journalist's assessment: "Even if he had done nothing else, Marx would deserve to be remembered as one of the great nineteenth-century journalists" (Wheen 2007, xiii). 


\section{Conclusion}

This paper has taken up two facets of Marx's writing, the Grundrisse and his journalism, that have heretofore not been presented together. The former was a work of Marx's middle years bridging and moving beyond the early writing on ideology and culture and his later work on political economy. Marx practiced journalism throughout his life but the middle years were also a time of his strongest journalism when he served as foreign correspondent for the New York Tribune. Whereas the Grundrisse suggested ways to theorize knowledge and communication labour, his journalism demonstrated how to practice it with passion and intelligence. These are lessons that communication students, and not just Marxist scholars, would do well to learn.

\section{References}

Berlin, Isaiah. 1970. Karl Marx: His Life and Environment. Oxford: Oxford University.

Dyer-Witheford, Nick. 1999. Cyber-Marx: Cycles and Circuits of Struggle in High Technology Capitalism. Urbana and Chicago, IL: University of Illinois Press.

Gledhill, Ruth. 2008. The Archbishop of Canterbury Speaks in Support of Karl Marx. Times Online, September 24.

Accessed December 14, 2011. http://www.timesonline.co.uk/tol/comment/faith/article4819605.ece

Gorz, André. 2010. The Immaterial. London: Seagull

Hardt, Hanno. 2001. Social Theories of the Press. Lanham, MD: Rowman and Littlefield.

Hardt, Michael and Negri, Antonio. 2004. Multitude: War and Democracy in the Age of Empire. New York: Penguin.

Kapital Gains, 2008. Times Online, October 20. Accessed December 14, 2011.

http://www.timesonline.co.uk/tol/comment/leading_article/article/4974195.ece

Ledbetter, James. Ed. 2007. Karl Marx: Dispatches for the New York Tribune. London: Penguin.

Marx, Karl. 1973. The Grundrisse. Trans. by Martin Nicolaus. London: Penguin.

Marx, Karl. 1974. Debates on Freedom of the Press and Publication. In Karl Marx on Freedom of the Press and Censorship, edited by Saul K. Padover, 3-47. New York: McGraw Hill.

Marx, Karl. 2007a. English Atrocities in China. In Karl Marx: Dispatches from the New York Tribune, edited by James Ledbetter, 20-24. London: Penguin.

Marx, Karl. 2007. History of the Opium Trade (II). In Karl Marx: Dispatches from the New York Tribune, edited by James Ledbetter, 28-31. London: Penguin.

Negri, Antonio. 1991. Marx beyond Marx. London: Pluto.

Nicolaus, Martin. 1973. Foreword. Grundrisse, 5-66. London: Penguin.

Nichols, John. 2011. The "S" Word: The Short History of an American Tradition ... Socialism. London: Verso.

Panitch, Leo. 2009. Thoroughly Modern Marx, Foreign Policy, April 15. Accessed December 14, 2011. http://www.foreignpolicy.com/articles/2009/04/15/thoroughly_modern_marx

Piccone, Paul. 1975. Reading the Grundrisse: Beyond Orthodoxy. Theory and Society 2 (2): 235-255.

Renzetti, Elizabeth. 2011. Springtime for Marx. The Globe and Mail, March 26, F5.

Saxena, Shobhan. 2008. Marx in the Time of Pink Slips. Times of India, 2 November.

Sherman, Steve. 2011. Marx as Journalist: An Interview with Jim Ledbetter. Accessed December 14, 2011. http://www.marxsite.com/Marx\%20as\%20a\%20Journalist.html

Terranova, Tiziana. 2004. Network Culture: Politics for the Information Age. London: Pluto.

Wheen, Francis. 2007. Foreward. In Karl Marx: Dispatches for the New York Tribune, edited by James Ledbetter, ix-xiii. London: Penguin, pp. ix-xiii.

\section{About the Author}

Vincent Mosco is Professor Emeritus of Sociology at Queen's University where he was Canada Research Chair in Communication and Society and head of the Department of Sociology. His most recent books include The Laboring of Communication (with Catherine McKercher, 2008), The Political Economy of Communication, second edition (2009), and Getting the Message: Communication Workers and Global Value Chains (edited with Ursula Huws and Catherine McKercher, 2010). 